\title{
Highly Skilled Migration from Lithuania: A Critical Overview of the Period 1990-2018
}

\author{
Liutauras Labanauskas ${ }^{1}$
}

\begin{abstract}
Central and Eastern European countries have been undergoing political, social, and economic changes since 1990. The process of international migration has been a cause for concern in many other new European Union member states (Poland, Bulgaria, and Romania in particular). Drawing from a diversity of theoretical works, this paper will attempt to analyze highly skilled migration from Lithuania, an Eastern European country with one of the highest emigration rates in Europe. It will analyze the trends in highly-skilled migration from/to Lithuania over the period of 1990-2018. The Lithuanian phenomenon of highly skilled migration has been argued to signify a qualitative shift in migration policy, from migration seen as a threat to migration/mobility as the main prerequisite of the knowledge economy and development potential. Insights from this analysis may later be used to contribute to analyzing the migration phenomenon in a more comparative regional perspective, as similar structural changes have taken place among the populations and within the labor force of all Central and Eastern European countries. Declining population size, worsening demographic indicators, aging, and labor-force shortages (especially among professionals) have become more and more pronounced.
\end{abstract}

\section{Keywords}

Brain drain • Highly skilled migration • Lithuania 
Central and Eastern European countries have been undergoing political, social, and economic changes since 1990. The process of international migration has been a cause for concern in many other European Union member states (Poland, Bulgaria, and Romania in particular). Migration in particular has left a deep impact on Central and Eastern European countries. Thus by building upon an empirical framework of mixed methods and drawing from a diversity of theoretical works, this paper will attempt to analyze highly skilled migration from Lithuania, an Eastern European country with one of the highest emigration rates in Europe. The aim of this paper is: 1) to clarify the social and economic factors predetermining the causes of highly skilled migration, 2) to analyze the trends in highly skilled migration from/to Lithuania over the period of 1990-2018, and 3) to present empirically based arguments that the Lithuania highly skilled migration phenomenon signifies a qualitative shift in migration, from being seen as a threat to migration/mobility to being the main prerequisite of the knowledge economy and development potential.

Although this article focuses only on analyzing highly skilled and economic migrations from Lithuania, the insights from this analysis may later be used to contribute to analyzing the phenomenon of migration in a more comparative regional perspective, as similar structural changes are also taking place among the populations and within the labor forces of all Central and Eastern European countries: Declining population sizes, worsening demographic indicators, aging, and labor-force shortages (especially among professionals) are becoming more and more pronounced. Thus, this article uses the term emigration of highly skilled persons to define the departure of a highly educated workforce from one country to another, usually for better wages or better working conditions. The concept of a highly skilled workforce varies from country to country, but most often highly skilled migrants are individuals who possess higher education levels or extensive experience, particularly in a specific sector of activity (Iredale, 2001). In this article, the author shall deem as migration any movement of highly skilled Lithuanian nationals moving abroad from Lithuania for more than a year, regardless of freedom of movement. Although this definition of highly skilled persons has shortcomings mainly related to data constraints, it aims to contribute to a better understanding of the highly skilled migration processes in Lithuania. Quantitative and qualitative research should be carried out in the future in order to investigate this topic further.

\section{The Role of Mobility and Migration as a Potential for Innovation: An Overview of Theoretical Models}

The hypothesis stating that both mobile and non-mobile highly skilled persons may contribute to the development of a country's national innovation system is not novel. In the literature, this hypothesis is constantly being checked based on one relational migration and innovation model or another. These particular models are briefly reviewed 
in the following section. Hart (2007), who analyzed the ways in which the migration of highly skilled persons contribute to innovation potential, suggested analyzing the expenditure (input) and output of the human capital; in other words, highly skilled migration is understood to be an input in the national innovation system. Young highly skilled persons who come to the destination country as students in particular are tied with the institutional, organizational, legislative and political-cultural context of that country; thus they have greater input in the infrastructure of innovation. The origination of innovation positively correlates to cultural diversity; namely, a culturally diverse labor force determines the origination of innovation (Niebuhr, 2010; Stuen, Mobarak, $\&$ Maskus, 2010). For example, Stuen, Mobarak, and Maskus (2010), who investigated employees from overseas who were working at universities in the USA, concluded that national diversity among scientists (not just being a foreigner per se) was the determinant factor in the increase in the amount of innovation. Florida (2005) also favors these conclusions and suggested cultural diversity to be the most important factor attracting workers who belong to the creative class to a certain country or region. The model for innovation supplementation states that the arrival of educated people to a country creates a flow of knowledge to certain sectors or areas as well as adjacent sectors and areas in that country, with innovation being the primary consequence of such flows of knowledge (Hunt \& Gauthier-Loiselle, 2009). For instance, Hunt and Gauthier-Loiselle analyzed the non-economic merits of migrants in the USA and calculated that $26 \%$ of scientists from the USA who had received Nobel prizes in 1999-2000 were migrants (notwithstanding the fact that the General Register of Immigrants shows only $12 \%$ of the population to be immigrants). These authors also calculated that, on average, an increase of $1 \%$ in the number of immigrants who possess higher education increases the number of patented inventions for one resident of the USA by $6 \%$. According to Hunt and Gauthier-Loiselle, the number of patents for one resident may increase due to the fact that local scientists use the knowledge that immigrants bring, which constitutes a critical mass of specialists in a specific field with the flow of knowledge eventually contributing to innovation in other secondary areas, such as management and enterprise (Hunt \& Gauthier-Loiselle, 2009).

Another migration and innovation model may be described as the model where immigration attracts highly skilled personnel. This model states that, although mass immigration is regulated through visa programs, the continuous flow of immigrants is actually maintained by the infrastructure of attraction; namely, the exceptional conditions that exist for studying or conducting scientific research in that country attract highly skilled persons to migrate there. Quite a number of authors have taken the point of view where infrastructure of attraction is the basis for their analysis of the input of highly qualified persons to the infrastructure of innovation. Chellaraj, Maskus, and Mattoo (2008), for example, have determined that the increased number of foreign students in master's degree programs in 
universities in the USA to form a positive correlation to the increase of the number of registered patents and inventions. Likewise, foreign doctoral students contribute quite a lot to science production; for example, a $10 \%$ decrease in the number of foreign doctoral students in USA universities decreases the number of articles in the fields of physical and engineering sciences and their respective citation levels by 5-6\% (Stuen, Mobarak, \& Maskus, 2010). Thus, although in summary the quantitative statistical evidence fluctuates on the input of foreign highly skilled persons to the creation of innovation, one can nevertheless state that possessing a critical mass of minds in a country is a positive stimulus for innovation and invention. Psacharopoulos and Woodhall (1997, p. 102) also claimed economic capital and natural resources to be passive factors of production while, at the same time, "Human beings are the active agents who accumulate capital; exploit natural resources; build social, economic, and political organizations; and carry forward national development." In this respect, the model of creative class that Florida (2005) developed is also worth mentioning. This model suggests that the gathering of personnel with immense knowledge in a particular field in a certain country, region, or city attracts other creative persons of similar thinking to that country, region, or city. In this way, the concentration of human capital and synthesis of ideas create the cycle of innovation encouragement and economic growth. A critical mass of personnel in a particular field in a country acts as a magnet that further attracts creative potential. Hence, the economic prosperity of a country depends both on physical and human resources; therefore both the material and economic capital together with the human resources of a "critical mass" of highly skilled persons are what determine countries' economic and social development.

The models from migration and innovation research mentioned above are based on quantitative parameters. Meanwhile, we may also find attempts in the scientific literature to analyze the transference of knowledge and innovation in terms of the qualitative aspect for investigating mobility and migration as a culture of knowledge acquisition and display (Williams, 2007). Namely, inter-human/inter-institutional relationships are the basis for the creation of innovation potential (Etzkowitz \& Leydesdorff, 2000). Knowledge lies in these relationships; therefore, two forms of knowledge become important when individual knowledge is comprehensively employed: tacit and explicit/precise knowledge (Allee, 1997). Tacit knowledge is the knowledge residing in the heads of individuals and groups due to their experiences, perceptions, beliefs, and values, as well as their rituals, culture, and learning, whereas explicit knowledge is most often documented knowledge (Harris, 2000). Contrary to tacit knowledge, explicit knowledge creates a definite result such as a product or service. According to Harris (2000), one should invest in enhancing tacit knowledge in order to increase the level of explicit and precise knowledge; in other words, one should invest in inter-human/inter-institutional relationships. Because knowledge lies 
in the inter-human/inter-institutional relationships and cooperation among individuals, the social and economic structure of a country or institution of transnational networks only provides greater opportunities for sharing explicit and tacit knowledge.

A vast number of researchers have focused on the brain drain debate in the context of highly skilled migration. The brain-drain phenomenon in migration studies is often referred to as a gray area as no universal definition or reliable statistics are found for brain drain. Brain drain can be described as an international, voluntary, legal, longterm or short-term, individual or collective, economic, and professional skilled labor migration. Such migration is caused by globalization and is discussed in the context of migration theories and the phenomenon of transnationalism. While analyzing the migration discourse in Lithuanian media, Marcinkevičienè (2004) provided a linguistic explanation for this concept. The metaphor of brain drain has negative associations and implies the vanishing of intellect, abilities, talent, knowledge, and wisdom. The meaning of the concept of brain drain never having been agreed upon among social scientists may be inferred Due to the application of this metaphor. The causes of brain drain are classified in different ways. Typically, the literature (Wolburg, 2001; Jucevičienè, Viržintaitè, \& Jucevičius, 2002) identifies the specific local characteristic (country, region) or global causes (e.g., globalization, multiple citizenships, transnationalism). These causes can also be described as external (the social, economic, legal, and cultural environment of a situation) and internal (the personal needs and aspirations of the situation). The most commonly identified push and pull factors are: difficulties in finding work at home; low salaries; poor living conditions; the desire to live with family (chain migration); career ambitions; unbalanced workload; and a country's historical, social, political, and cultural heritage. Factors such as labor shortages in certain sectors and aggressive foreign country policies for attracting labor are also significant. Networks of highly skilled persons (scientific diaspora) are also a significant pull factor. Highly skilled professionals' being very likely to trust each other and therefore share their experiences in matters relating to career is widely believed (Jucevičienè, Viržintaitè, \& Jucevičius, 2002). Individual-level causes of brain drain result from macro-level factors. Imbalance between labor supply and demand is a part of the higher education system, which prepares plenty of skilled professionals; this plentitude results in a skills gap and risk of structural unemployment. The departure of talented scientists and professionals - the country's intellectual capitaldecreases competitiveness in certain areas of economy, especially relating to the intellectual capital of technology and R\&D. In transition countries, the brain-drain phenomenon poses a serious threat not only to socioeconomic development but also the development of a middle-class. Although fierce debates exist over the term social class, the Lithuanian middle class can be said to be small and to make up $20 \%$ of the total population (Taljūnaite, 2005; Morkevicius \& Norkus, 2017; Taljunaite \& Sviklas, 2018). The abundance of doctors, engineers, IT professionals, and other professionals 
is a pre-condition not only for economic growth but also for enabling a stable democratic society, whereas emigration complicates the middle strata development and facilitates the development of bureaucracy, corruption and irresponsible governance (Jucevičiené, Viržintaitè, \& Jucevičius, 2002). Talent development and knowledge work contribute to national economic growth, research, innovation, and promotion of entrepreneurship. When knowledge workers arrive in a country, their arrival results in a chain effect where skilled immigrants are able to help employers attract more highly skilled workers; thus no need exists for additional spending on education (Dobravolskas, 2001; Hart, 2007; Niebur, 2010). Another advantage of highly skilled immigration is increased competitiveness. In summary, highly skilled migration and a country's overall macroeconomic situation can stated as interdependent. One important but highly under-researched aspect of migration relates to value orientations. The literature has argued the importance of including value orientations as a powerful explanatory migration variable. For example, some have used Eurobarometer lifesatisfaction scores and concluded the propensity for migration to be even more highly correlated with life satisfaction than with GDP per capita (Blanchflower, Saleheen, \& Shadforth 2007; Blanchflower \& Shadforth, 2009). Prytula and Pohorila (2012) based their analysis on Herzberg's motivation theory and proved the rates of emigration to be lower in nations with a high prevalence of intrinsic values (e.g., personal selffulfillment, job task content). Meanwhile, emigration rates are higher in nations with a prevalence of strong extrinsic work values (salary level, physical working conditions, and working hours; Prytula \& Pohorila, 2012). According to Prytula and Pohorila, extrinsic values may be conducive to emigration because they are prevalent in periods of social instability (Ardichvili, 2009). To sum up, migration studies have been slow to engage critical debates on values and norms, and little research has been conducted on analyzing the meaning of migration in order to understand the mental models that shape the way migrants think about trust, competition, authority, and other critical variables for values.

\section{Highly Skilled Migration from Lithuania: The Impact on Society and Policy Responses 1990-2018}

Lithuania remains a potential source for a highly skilled labor force. The 2011 Census (Statistics Lithuania, 2012) data revealed that since Lithuania regained its independence in 1990 , almost 670,000 people ( $18 \%$ of the country's total population) were living abroad for more than one year. Of these, the majority were aged 25-40 and economically active; $20 \%$ of them were highly skilled or had had tertiary education. Return migration and immigration have been rather insignificant for maintaining healthy levels of population growth. The return migration for the period of 1990-2018 was rather low, and immigration levels were never high (Statistics Lithuania, 2018). 
Since 1990, the policy debate on highly skilled knowledge workers leaving Lithuania has centered on the brain-drain phenomenon. The emigration of highly skilled persons out of the country is generally agreed to have been encouraged by the political, economic, and social changes that started after reestablishing independence. Demographic unbalances, differences in wages, outdated technical and scientific infrastructures, and structural changes in scientific institutions have predetermined the departure of highly skilled persons to other countries. The country was affected by economic developments through the globalization of economic activity, which was related in many aspects to changes in the Lithuanian labor market and membership in the European Union (EU). After Lithuania joined the EU in 2004, it began exporting its workforce, a significant portion of which was well qualified and highly skilled. The academic debate on emigration-immigration of highly skilled persons in Lithuania can be divided into four overlapping phases:

1. The legacy of the Soviet period 1990-2003;

2. Economic migration/emigration: EU freedom of movement and the brain-drain discourse 2004-2009;

3. 2009 and onward... oriented on researchers forming transnational networks and knowledge transfer

4. Immigration and return migration debates beginning in 2014 .

Here we present a critical overview of the highly skilled migration trends in Lithuania from 1990 to 2018. The insights of this analysis may be later used to contribute to analyzing the migration phenomenon in a comparative regional perspective as similar structural changes are also taking place among the populations and within the labor forces of all Central and Eastern European countries.

\section{The legacy of the Soviet period: 1990-2003}

The problem of highly skilled persons emigrating from Lithuania first entered the academic debate when Lithuania first gained its independence. Highly skilled and knowledgeable workers' emigration has often been perceived as dangerous (Jucevičiené, Viržintaitè, \& Jucevičius, 2002; Stankuniene, 1996), and the academic discourse often refers to the emigration of highly skilled persons as brain drain and brain waste. The issue of brain gain (attracting intellectual capital from abroad) has not been researched at all in this period. In the first study on brain drain, conducted in 1995 (see Stankuniene, 1996) an intensive flow of researchers was observed to other branches of the national economy as well as the sizeable emigration frequently being characterized as brain waste rather than brain drain (Stankuniene, 1996). To present the exact data on highly skilled persons leaving Lithuania in this period is problematic due to the lack of statistical 
data and sociological research. The changes in Lithuania's political situation had the greatest effect on the branches of science that had been most integrated into the economic, scientific, and ideological structures of the former Soviet Union. Two emigration strategies prevailed in this period: 1) departures to the former USSR as departing researchers were familiar with the working conditions or departing to their ethnic homeland (mainly Russia); 2) departure to Western countries that was affected by several stages: temporary migration in the initial period and a permanent emigration in the later period, which in many cases resulted in brain waste (Stankuniene, 1996). 1995 survey data on the potential of emigration revealed that over $80 \%$ of researchers had considered the possibility of moving abroad (Stankuniene, 1996), but not all of them had actually moved. The survey also revealed that researchers who thought their work was needed in Lithuania and state institutions were interested in their research were less likely to emigrate. In contrast, researchers who thought nobody in Lithuania was interested in their research were more inclined to work abroad (Stankuniene, 1996). The transnational networks between the former Soviet republic and Western researchers were likely weak and unstable and did not facilitate mobility. Russia became the main destination country for Lithuanian researchers from 1988 to 1994, with 22.3\% emigrating there. Other destinations included the USA (19.1\%), Germany (8.5\%), and Scandinavian countries (7.4\%; Stankuniene, 1996). Although the literature has stated nearly half of all migrant researchers to be involved into some research activity (Stankuniene, 1996) on can still infer from the data that emigration to Western countries frequently resulted in brain waste. Those few individuals who managed to successfully integrate into the Western or American research infrastructure later became important migration network agents who could later facilitate the arrival and adaptation of their colleagues.

During period of 1995-2003, the geographical direction of the brain drain changed gradually from Eastern to Western countries such as Germany, the USA, France, Scandinavian countries, and the UK. However, precise data on the geography of brain drain has never been collected. This period was also characteristic of the shift from widespread research collaboration with Russian researchers to a more widespread collaboration with Western researchers (joint research projects, international funding schemes, and international publications). The available statistical data from this period only reflect the general emigration rates; this doesn't allow the scope of highly skilled emigration to be revealed.

Another study on highly skilled migration was conducted in 2002 (Jucevičiené, Viržintaite, \& Jucevičius, 2002). This study demonstrated perceptions of a good life to be dominated by economic values like financial security. It also revealed socialcultural factors such as local environment and participation in cultural life to be of relatively less importance in the decision to migrate. The study also demonstrated researchers' preference for the expert-type career path in a rather stable Western research 
environment system rather than a preference for possibly contributing to influencing, creating, and developing a new local research environment. The study also demonstrated that the advantages offered by foreign environments (pull factors) were emphasized more than domestic drawbacks (push factors). The 2002 study also demonstrated that researchers were willing to maintain ties with their homeland, did not deny the prospects of returning, and proposed a policy framework oriented toward: (1) creating conditions/ incentive systems for keeping intellectual capital at home and (2) making the best use of ties with the emigrant intellectual capital (Jucevičienè, Viržintaite, \& Jucevičius, 2002). Thus, the policy discussions that emerged were based on these conclusions and became the prerequisites for the gradually emerging debate on transnational research networks and their influence on the decision to migrate.

When taking the aspect of policy into account, mentioning that the last five years of the period from 1990 to 2003 were marked by Lithuania's ambition to finally join the EU (which happened in the spring of 2004) is important. Lithuania's research and education system had the prerequisite to evolve from a highly ideological and domestic system to a more open, internationalized system of research and education. As a result of the gradual implementation of Western-oriented research policies and strategies, a system of research and education provided the platform not only for improvements in knowledge exchanges between the East and the West but also for increased emigration of highly skilled persons, especially in the fields of technology and biomedicine.

\section{Economic migration and the brain-drain discourse: 2004-2009}

This intensive emigration can be characterized by a high increase in the numbers of unskilled workers moving towards developed Western countries (especially Ireland and the UK) for low- or semi-skilled jobs; it is the beginning of the brain-drain debate as a grey zone in migration research. During this period, Lithuania experienced a high rate of labor emigration that peaked during the early years of EU membership (2004-2008) and later during the economic and financial crisis (2009-2011). This has had some far-reaching economic and social effects, including a significant increase in emigration, brain drain, and brain waste, and a worsening demographic balance. The Economic Migration Regulation Strategy was adopted in 2007 and aimed at responding to the demographic challenges caused by economic migration. It outlined the long-term priorities of the Lithuanian migration policy, underlining return migrations and reducing emigration particularly for young populations and the highly skilled. The main objectives of the strategy were the zero reduction of emigration, focusing on promoting return migration, and immigration from third countries. However, the Economic Migration Regulation Strategy was adopted just before the global economic crisis and this can be considered the main reason why it failed to reach most of the objectives that were set up in the strategy. The strategy 
also included many declarative statements and no reliable mechanisms of interinstitutional cooperation for its implementation.

Kazlauskiene and Rinkevicius (2006) analyzed highly skilled emigration from Lithuania in this period with a particular focus on social capital. In their study, six main channels of social ties were revealed as having the most significant role in the highly skilled deciding to migrate. According to Kazlauskiene and Rinkevicius (2006), the academic institutions the would-be migrants had visited prior to deciding to migrate had essentially acted as channels of information about working conditions abroad. Family members abroad were also significant facilitators in the migration process, especially for younger or older less-skilled persons, whereas academic mobility funds served as the primary source of financial support for the highly skilled. Foreign Lithuanian communities were also reported as universal aid providers, especially for the highly skilled or older persons (Kazlauskiene \& Rinkevicius, 2006). Their research also revealed the importance of weak institutionalized ties in highly skilled migrations, whereas strong family ties were more important in lessskilled migration. One can possibly conclude from Kazlauskiene and Rinkevicius's research that this may signify the beginning of the formation of transnational networks of highly skilled persons through weak ties among national and international research and education institutions. This was an important step for scientists' further increases in knowledge mobility and the formation of transnational networks. Aidis and Krupickaite (2009) also concluded the propensity for youths (students as a potential brain-drain pool) to migrate to be related to the attitudes and values within the family. The authors distinguished two groups of students. The first group was motivated for self-realization at home, while the second group was motivated to work and earn more abroad.

Another significant trend in research on highly skilled migration in this period was on professional groups; however, only one study was found in this period, and it focused on the potential of highly skilled medical professionals (Labanauskas, 2006). The case study of nurses and physicians at Vilnius University's Institute of Oncology discussed the brain drain issue in the context of the free movement of people after the EU's enlargement. On one hand, free movement of persons is considered an optimum condition for political, economic, social, and cultural transformations within society; on the other hand, however, the study argued that the brain drain will have a negative impact on Lithuania as the country is in transition. Together with the empirical study of physicians and nurses, this study also theoretically discussed somewhat the potential for brain drain among information technology specialists and researchers in Lithuania. These groups of the population were revealed to have been the most vulnerable to the brain-drain phenomenon (Labanauskas, 2006). 
In conclusion, the latter 2004-2009 period for highly skilled migration research can be said to be marked by two main trends. Firstly, research on highly skilled migration loaded itself with values as many authors (including myself) perceived the emigration (or mobility) of the highly skilled mainly as a threat to societal cohesion and economic/ social stability. Secondly, research on highly skilled migration focused only on emigration, ignoring the issues of immigration. Moreover, research on highly skilled migration was only national with no comparative studies being conducted.

\section{The debate on the formation of transnational researcher networks, knowledge transfers, and immigration}

Since 2009, the debate on highly skilled migration has centered on such issues as the formation of transnational researcher networks, knowledge transfers, and immigration. In 2009, the new Law on Higher Education and Research was adopted. This law aimed at a radical restructuring of the Lithuanian higher education system. The declared objective of the law, which had been referred to as an education reform, was to improve higher education and training through: 1) a new funding model in higher education (student's basket), 2) the internationalization and marketization of higher education, and 3) the optimization of higher education institution networks (universities, colleges, and research institutes). After the law was introduced in 2009, higher education in Lithuania was no longer viewed as a contributor to economic development but rather as a cost. Firstly, despite the consolidated political will and authority of Lithuania's Ministry of Education, the higher education system still had inefficient resource allocations and was generally perceived as having low quality. Secondly, a mismatch remained between the cost and quality of higher education, with concerns that these might act in the long run as a push factor for studying abroad (a positive outcome), but would later gravitate to the permanent emigration of highly skilled people. A survey carried out in 2010 by the National Union of Student Representations of Lithuania at the 50 best-performing secondary schools revealed that $16 \%$ (one out of six) of these school graduates had already applied to study abroad. Graduates from the three leading secondary schools (KTU Gimazija, Kaunas J. Basanavicius Secondary School, and National M. K. Ciurlionis Art School) were ranked as being the most susceptible to emigration: $40 \%-60 \%$ of these best performing secondary school graduates had applied to study abroad (Lietuvos Studentų Atstovybiu Sajunga, 2010).

Another migration trend of the highly skilled since 2009 can be considered in terms of the international and transnational mobility as a global career strategy for many young Lithuanian students (Labanauskas, 2013). A qualitative study on Lithuanian students who had studied abroad and returned to Lithuania after finishing their studies revealed young Lithuanian students' educational mobility to be a very complex 
phenomenon (Labanauskas, 2013). Their mobility was based on communication and culture, but not necessarily on territorial attachment. The study's subjects emphasized the importance of the global lifestyle, a cosmopolitan world without borders. Thus, their departure for studying abroad cannot be termed emigration in the classical sense of the concept. Their mobility and return were rather repetitive, but by no means exhaustive or a final phenomenon. Some students' return to Lithuania clearly had an innovative character in that these returnees were challenging the existing ways of doing and thinking, especially in the work environment. More so, the returnees in many cases were not able to employ their high qualifications and highly developed social competences due to the public sector's resistance to knowledge and innovation, despite the fact that a good foreign university diploma gave the informants more life opportunities in the Lithuanian labor market. The study concluded that returnees' competitive advantage had mainly been predetermined in the labor market by two key factors. The first, an internal factor, was the tacit knowledge and developed social competencies that determined the returnees' successful performance at work. The second was the fact that a foreign university diploma in Lithuania as a country with high social inequality had acquired the status of being a rare, expensive, and desirable good that was rather overestimated by employers.

Because of the loss of domestic human capital, by 2009 immigration was likely to gradually reshape the Lithuanian labor market as well as the education system. Thus, the brain-drain debate had shifted towards a discussion on whether skilled immigration could stimulate the country's economic growth or whether highly skilled immigration might bring added value to the country's science and business infrastructures. Immigrant integration measures were put in place in 2009 (better access to the labor market than most Baltic States; Migration Integration Policy Index [MIPEX], 2014) as an increase in the immigrant population was expected over the long run (taking into account the possible impact of formal higher education providers' and employers' active recruitment measures). Thus, taking immigrants into consideration while preparing labor-market and education policies or strategies at the national or institutional levels had already became a necessity for boosting the labor market and education sectors. Developing inclusive integration and education policies became part of the official discourse.

However, the reality immigrants in Lithuania faced differed quite a bit from the official policies. A qualitative study of 45 adult newcomers ( 28 having permanent or temporary residence status) revealed that adult immigrants' restrictions or nonparticipation in Lithuanian society through the target language had mainly been related to the lack of educational language learning resources targeting this specific group, considering that the materials currently in local use had been devised before Lithuania became an EU Member-State (Zygmantas, 2011). Furthermore, apart from study purposes, the willingness of these learners to do business in Lithuania (not for citizenship 
purposes) was among the most significant reasons for learning the local language (Zygmantas, 2011). Another study (commissioned by The Lithuanian Ministry of Education and Science and carried out by the Lithuanian Social Research Centre in 2009) focused on the immigration policies and practices relevant to non-EU researchers and highly skilled employees in Lithuania. A qualitative study was carried out with non-EU researchers in Lithuania (see Taljunaite, Gumbreviciute, \& Labanauskas, 2009). The study included researchers and scholars who had: lived in Lithuania for more than 6 months, were working under an employment contract, or were full-time doctoral students at a university or research institute in Lithuania. The study revealed no accurate data to be exist on the highly skilled in Lithuania and the data on the highly skilled from non-EU countries to be very limited. Highly skilled persons dissolve into overall immigration statistics. Based on these figures up to 30 non-EU researchers can be estimated to have been in Lithuania in 2009. Given the fact that the number of those with doctorates had not changed drastically, we can imply the number of foreign researchers to have not changed much. A study of non-EU researchers also proposed a typology of the highly skilled who come to Lithuania (see Table 1).

Table 1

The Typology of non-EU Researchers in Lithuania (2009)

\begin{tabular}{|c|c|c|}
\hline $\begin{array}{l}\text { Type according } \\
\text { to immigration }\end{array}$ & Researchers in Lithuania & Notes \\
\hline \multirow[b]{5}{*}{ Motivation } & $\begin{array}{c}\text { Came to gain international } \\
\text { experience/improve their } \\
\mathrm{CV}++\end{array}$ & Early stage researchers/PhD students. \\
\hline & $\begin{array}{l}\text { Attracted by money/scholar- } \\
\text { ships (origin state allocated } \\
\text { funds, exchange, double de- } \\
\text { gree, competitions, or other } \\
\text { programs as well as project } \\
\text { funding) }++\end{array}$ & Early stage researchers/PhD students. \\
\hline & $\begin{array}{l}\text { Attracted by outstanding } \\
\text { research centers? }\end{array}$ & Little practice; No cases found \\
\hline & Job vacancy? & $\begin{array}{l}\text { Local recruitment procedures were not orientated toward } \\
\text { the international job market. }\end{array}$ \\
\hline & $\begin{array}{l}\text { (Invited) for development } \\
\text { purposes? }\end{array}$ & $\begin{array}{l}\text { Developed countries seek to ensure development of the } \\
\text { country, and aim to attract foreign researchers through } \\
\text { various programs and initiatives. This is particularly } \\
\text { true in the health care and IT sectors. In 2006, Lithuania } \\
\text { launched the brain-return program, which aimed to pro- } \\
\text { mote return migration and research/development through } \\
\text { international co-operation with Lithuanian scientists } \\
\text { abroad. } \\
\text { However, the brain-raising initiative was largely deter- } \\
\text { mined by interpersonal relations, not institutionalized } \\
\text { ones. In 2009, the Lithuanian government approved the } \\
\text { Researcher Career Program, which provided funding for } \\
\text { scholars from outside Lithuania for their arrival over a } 24 \\
\text { months period; however, no guidelines were provided on } \\
\text { the selection criteria for researchers from abroad. }\end{array}$ \\
\hline
\end{tabular}




\begin{tabular}{|c|c|c|}
\hline \multirow[b]{2}{*}{ Country } & $\begin{array}{l}\text { From developed countries } \\
\text { to developing/transitional } \\
\text { countries }+\end{array}$ & $\begin{array}{l}\text { Lithuania as an immigration country is chosen not only } \\
\text { as a place to carry out research but also for economic } \\
\text { reasons. The study shows researchers entering Lithuania } \\
\text { from developed countries to largely be determined by the } \\
\text { advantage of cost-of-living differences. }\end{array}$ \\
\hline & $\begin{array}{l}\text { From developing/transitional } \\
\text { countries to more developed } \\
\text { countries }+\end{array}$ & $\begin{array}{l}\text { Research has shown that immigration from developing } \\
\text { countries to be instrumental (e.g., obtaining a residence } \\
\text { permit/citizenship and freedom to move to another EU } \\
\text { country; or arriving from countries with relatively expen- } \\
\text { sive and lower education levels with the aim of returning } \\
\text { to the country of origin. }\end{array}$ \\
\hline \multirow{5}{*}{ Channel } & Employment + & \multirow{5}{*}{$\begin{array}{l}\text { The study shows third-nation researchers to often take } \\
\text { unsafe jobs based on a short-term fixed-term contract or } \\
\text { longer (up to 4-year scholarships). }\end{array}$} \\
\hline & Science/Research + & \\
\hline & Study + & \\
\hline & Project activities - & \\
\hline & Business research? & \\
\hline \multirow[b]{3}{*}{ Duration } & $\begin{array}{c}\text { Short-term (up to } 6 \text { months.) } \\
\qquad+\end{array}$ & \multirow{3}{*}{$\begin{array}{l}\text { Short- and medium-term visits are the most characteristic } \\
\text { feature of highly skilled immigration to Lithuania. The } \\
\text { internationalization of undergraduate studies can produce } \\
\text { a new generation of scientists. However, it is expen- } \\
\text { sive. On the other hand, initiatives promoting long-term } \\
\text { employment should be evaluated carefully. Properly } \\
\text { assessing the potential of Lithuanian researchers and } \\
\text { growing a new generation of researchers through educa- } \\
\text { tion are important. }\end{array}$} \\
\hline & Medium-term (1-3 years) + & \\
\hline & $\begin{array}{l}\text { Long-term (more than } 3 \\
\text { years) - }\end{array}$ & \\
\hline \multirow[t]{3}{*}{ Workplace } & Work in less-skilled jobs? & $\begin{array}{l}\text { Some developed countries seek to attract experienced } \\
\text { researchers from poorer countries to lesser-skilled jobs. If } \\
\text { Lithuania behaves similarly in the future, the labor mar- } \\
\text { ket would become significantly distorted by the fact that } \\
\text { Lithuanian researchers would have fewer opportunities } \\
\text { for finding employment. }\end{array}$ \\
\hline & Neutral workplace? & $\begin{array}{l}\text { International recruitment and selection procedures are not } \\
\text { common inside universities and research centers. }\end{array}$ \\
\hline & $\begin{array}{l}\text { Exclusive/prestigious work } \\
\text { position? }\end{array}$ & $\begin{array}{l}\text { If foreign researchers in Lithuania would be employed } \\
\text { only in exceptional jobs, the attractiveness for locals to } \\
\text { pursue a career in science would decrease. }\end{array}$ \\
\hline
\end{tabular}

This table is from Taljunaite et al., 2009 and is based on Iredale's (2001) typology.

++ rather frequently; + a few cases; - very few; ? no information;

The mentioned qualitative study reveals that non-EU researchers in Lithuania learned to become an invisible social group (Taljunaite et al., 2009). Contacts with the majority of Lithuanian society were limited to professional and work relationships with the exception of spouses and close friends. Their contacts with the country's symbolic (citizenship) or social institutions were self-limited, as non-EU researchers in Lithuania automatically set themselves apart from the rights and obligations to the host country. Namely, they feel they are tolerated and accepted; economically and socially they feel more or less safe but don't feel they belong; and they consider themselves migrants par excellence (Taljunaite et al., 2009). 


\section{The debate on immigration and return migration beginning in 2014}

After the 2004 EU enlargement, migration became a massive social process influencing all spheres of life. Since 2014, Lithuanian migration policies shifted towards a more immigrant-friendly migration policy; however, it was directed towards return migration rather than toward attracting non-Lithuanian highly skilled migrants or migrant integration. Before 2014, Lithuania had no strategy of immigration policy based on long-term goals; priorities and immigration policy were based on migratory behavior and on the so-called ad-hoc approach (Žibas, 2015a). Highly skilled migration from/to Lithuania and the state policy in this respect were issues of relatively low significance; they did not constitute an important element of Lithuanian policy regulations (Žibas, 2015a). In 2014, the Lithuanian Migration Policy Guidelines were adopted, which aimed at ensuring the management of migration flows in line with national needs and to contribute to national development and social cohesion. In 2011, the program Global Lithuania, as well as action plans for implementing the program from 2011 to 2019, were adopted with an aim to involve Lithuanian emigrants in the life of the state with a focus on regulating emigration policies, particularly those concerning Lithuanian migrant communities abroad. Global Lithuania (2011) and Lithuanian Migration Policy Guidelines (2014) prioritized return migration and attempts to reduce high outflows of the Lithuanian population. In 2014, the Lithuanian Migration Policy Guidelines identified the main priorities in the area of immigration: emigration, return migration, immigration, migrant integration, asylum, the fight against illegal migration, and issues related to the institutional development of the implementation of migration polices. Labor-related immigration became visible in public discourse, as it had triggered debates on the demand for a new approach towards labor-immigration and migrant-integration policies (Žibas, 2015a). However, highly skilled migration issues were only a small part of policies.

When analyzing the legislative and institutional developments in migration management in Lithuania since the restoration of independence, the Lithuanian Migration Policy Guidelines appear as the very first step towards long-term strategy and a vision of migration management in Lithuania (MIPEX, 2014). The amendments to immigration laws were aimed at benefitting from the integration of a few non-EU immigrants, including a very small number of highly skilled persons who had been admitted in recent years (MIPEX, 2014). The Migration Policy Guidelines set out a special chapter on the Integration of Foreigners, and the Social Security and Labour Ministry created a multi-stakeholder work group and finally an Action Plan on the Integration of Foreigners, which intends to lead to new support measures and concrete policy changes in 2015 and beyond (MIPEX, 2014). Consequently, these guidelines seemed to address the increasing number of new immigrants, especially the increased number of foreign students (e.g., for the past several years the number of non-EU students enrolling in a full-time study program has consistently increased from 1,600 
in 2011-2012 to around 4,600 in 2015 (but in comparison to other EU countries, these numbers are very low; within the general immigration context, international students amount to $10-15 \%$ of all arriving non-EU nationals, or around $2 \%$ of all students; the Ministry of Education and Science seeks to increase the number of foreign students 5- to 6-fold; namely, to increase the number of foreign students to 15,000-20,000 per year (International Organisation for Migration, European Migration Network, 2012). Despite this, however, the Ministry of Education and education experts have come to regard foreign students as a potential of highly skilled immigration. As Lithuanian universities face problems with recruitment caused by a demographic decline, no sufficient integration measures are found to be aimed at non-EU researchers or the international students who face problems with complicated residence permit procedures (Taljunaite et al., 2009), discrimination, and hate crimes (Labanauskas, 2019). The inflow of non-EU students is not able to make up for the loss of students resulting from Lithuanian students studying abroad and the out-migration of Lithuanian youths. Moreover, despite some inclusive migration policy measures, the country's labor market is not attractive to immigrants who might want to stay in the country and integrate; schools are poorly prepared to accept immigrant children as they lack the basic infrastructure. Immigrants do not have equal access to general health services, the rights of migrants to participate in the country's political life is restricted, and immigrants have a long and complicated road to becoming citizens (Žibas, 2015b).

\section{Discussion}

This article has aimed to analyze the trends in highly skilled migration in Lithuania over the period of 1990-2018. However, research on skilled migration or mobility patterns in Lithuania have clearly often been based on the explanations of economic push-pull migration models. While analyzing highly-qualified migration in Lithuania, three closely inter-related research areas can be distinguished: 1) macro-level analysis of the economic factors of highly skilled migration; 2) analysis of the individual (micro- and mezzo-level) causes and consequences of migration, and 3) analysis of highly skilled persons' propensity to migrate. Although structural/environmental factors such as political changes, economic variables, and social networks have important effects on international highly skilled migration, people respond to external conditions through behaviors that are often mediated by values, subjective perceptions, intentions, and goal-setting. The migration (movement or mobility) of knowledge and highly skilled workers is more a permanent condition than a finished and completed action. Thus the movement of highly skilled persons between countries is determined not only by economic considerations but also by the subjective individual's relationship with the state. Such subjective relationships manifest mainly through the context of normative values. For example, the empirical data in highly skilled migration research demonstrate that decisions to return are more motivated by values and norms than by 
economic motives. In other words, while the main reasons for emigrating remain as economic considerations (low paid jobs combined with high responsibilities), the most significant reasons for returning have a normative and psychological character (i.e., the informants have a rather clear vision on how things in their homeland should or ought to be, how to value them, and which things are good/bad). In addition, the migration experience provides resources for acting more effectively in relation to the state environment and may instigate incentives to reform this environment.

Over the period of 1990-2018, the phenomenon of Lithuanian highly skilled emigration signifies a qualitative shift in migration policy from migration seen as a threat, to the development of society, to migration/mobility as the main prerequisite of knowledge economy and a potential for development and brain circulation/exchange. We may conclude that, since 1990, Lithuania has followed a non-interference neoliberal policy approach for almost 30 years, as migration processes were not regulated until 2007 when the Economic Migration Regulation Strategy was adopted. However, as it was adopted just before the global economic crisis, it failed to reach most of its declarative objectives without any reliable mechanisms for implementing interinstitutional cooperation. Since 2014 after the Lithuanian Migration Policy Guidelines were adopted, the state has started to intervene in the regulation of migration flows internally through administrative, legal, and economic measures with a particular focus on diaspora networks, encouragement of return migrations, the maintenance of Lithuanian identity, engagement in the life of Lithuania, and transformation of the brain drain into brain circulation/exchange. In 2014, emigration flows from Lithuania started to decline, whereas the number of Lithuanian return migrants started to grow (Statistics Lithuania, 2014). However, despite these policy measures, highly skilled Lithuanians have made considerable use of the opportunities that free movement gives to EU citizens; in the context of transnational migration flows, Lithuania remains a highly skilled emigrant country, and emigration continues to be the dominant highly skilled migration pattern in Lithuania.

The purpose of this exploratory paper has also been to identify patterns and analyze changes in highly skilled migration from Lithuania since 1990. Though this research has been descriptive, we can reach some generalizations from this level of analysis. Firstly, highly skilled migration patterns had reacted to social and political changes (e..g, the fall of the Soviet Union, joining the European Union, migration policy changes and education reforms that both triggered emigration, return migration and immigration of the highly skilled). Secondly, the free movement of workers, one of the fundamental rights enjoyed by European citizens, has facilitated highly skilled emigration from Lithuania. Despite the changes in migration policy, the country still sends its educated workforce to regions within the EU to the advantage of the receiving countries, which results in a growing competition for talent and the limited capacity of Lithuania to 
create attractive conditions for highly skilled persons. Thirdly, highly skilled migration patterns have changed over time, as well as social and political agendas with respect to migration issues such as integrating immigrants; return migration has changed as well but the problem has failed to be addressed. Finally, policies for attracting and retaining highly skilled persons have been introduced; however, the scope and implementation of these policy measures are insufficient at addressing the qualitative shift in migration policy from migration being seen as a threat to migration/mobility as the main prerequisite of a knowledge economy and potential for development. The institutional and social barriers of attracting highly skilled persons remain, from administrative restrictions; to obtaining work and residence permits; and to xenophobia, racism, discrimination, and hate crimes. The measures and incentives stimulating the return of highly skilled persons remain rather sporadic and inconsistent. The information and research on how migration processes affect men and women differently and in different cities and regions in Lithuania still remains insufficient. Ethnic relations, religion, and race, as well as highly skilled youths with a migration background remain understudied areas in migration research in Lithuania.

\footnotetext{
Peer-review: Externally peer-reviewed.

Conflict of Interest: The author has no conflict of interest to declare.

Grand Support: The author declared that this study has received no financial support.

Hakem Değerlendirmesi: Dış bağımsız.

Çıkar Çatıșması: Yazar çıkar çatışması bildirmemiştir.

Finansal Destek: Yazar bu çalışma için finansal destek almadığını beyan etmiştir.
}

\section{References/Kaynaklar}

Aidis, R., \& Krupickaitė, D. (2009). Kaip neǐ̌šsaistyti protų: Lietuvos studentų nuostatos emigruoti. Vilnius, Lithuania: Vilniaus Universitetas.

Aidis, R., Krupickaitè, D., \& Blinstrubaite, L. (2005). The loss of intellectual potential: Migration tendencies amongst university students in Lithuania. Geografija, 41(2), 33-40.

Allee, V. (1997). The knowledge evolution: Expanding organizational intelligence. San Francisco, CA: Butterworth-Heinemann.

Ardichvili, A. (2009). The relationship between meaning of working and socioeconomic transformations: The case of post-communist Russia. Advances in Developing Human Resources, 218-234. https://dx.doi.org/10.1177/1523422309332244

Blanchflower, D. G., \& Shadforth, C. (2009). Fear, unemployment and migration. The Economic Journal, 119(535), 136-182.

Blanchflower, D., Saleheen, J., \& Shadforth, C. (2007). The impact of the recent migration from Eastern Europe on the UK Economy (Discussion Paper No. 2615). Bonn, Germany: Institute for the Study of Labor.

Chellaraj, G., Maskus, K. E., \& Mattoo, E. (2008). The contribution of skilled immigrations and international graduate students to U.S. innovation (Policy research working paper series No. WPS 3588). Washington DC, World Bank. 
Dobravolskas, A. (2001). Laisvos darbo jègos judejimo padariniai. Integracijos Žinios, 5(25).

Etzkowitz, H., \& Leydesdorff, L. (2000). The dynamics of innovation: From national systems and "Mode 2" to a triple helix of university-industry-government relations. Research Policy, 29, $109-123$.

Florida, R. (2005). The flight of the creative class: The new global competition for talent. New York, NY: Harper Business.

Harris, L. (2000). A theory of intellectual capital. Advances in Developing Human Resources, 1, $22-37$.

Hart, D. M. (2007). Understanding immigration in a national systems of innovation framework. Science and Public Policy, 34(1), 45-53.

Hunt, J., \& Gauthier-Loiselle, M. (2009). How much does immigration boost innovation? (Discussion Paper No. 3921). Bonn, Germany: Institute for the Study of Labor. Retrieved from http://ftp.iza. org/dp3921.pdf

International Organisation for Migration, European Migration Network. (2012). International students in Lithuania. Vilnius: Author.

Iredale, R. (2001). The migration of professionals: Theories and typologies. International Migration, $7-26$.

Jucevičienè, P., Viržintaitė, R., \& Jucevičius, G. (2002). Protu nutekejjimo reiškinys ir jo atspindžio Lietuvos intelektiniame kapitale bruožai: žvalgomasis tyrimas. Vilnius, Lithuania: Lietuvos Mokslo Taryba.

Kazlauskienè, A., \& Rinkevičius, L. (2006). Sociological exploration of migration processes in. Lithuania: Brain drain or brain circulation? Social Sciences, 4(54), 42-49.

Labanauskas, L. (2006). Protų nutekejimo problema Lietuvoje: Medikų emigracija. Filosofija, Sociologija, 2, 27-34.

Labanauskas, L. (2013). Jaunimo ịgijusio išsilavinimą užsienyje "sugrịžimo ị Lietuvą" patirtys. Lietuvos Etnologija: Socialinès Antropologijos Ir Etnologijos Studijos, 13, 35-57.

Labanauskas, L. (2019). Response to hate crime and hate speech in Lithuania (Manuscript submitted for publication). Vilnius, Lithuania.

Lietuvos Studentų Atstovybių Sajunga. (2010, May 21). Tyrimas: Kas šeštas iš gabiausiujų abiturientu ruošiasi studijuoti užsienyje. Retrieved from http://www.lsas.lt/?id=7\&nid=560

Marcinkevičienè, R. (2004). Emigracija spaudoje: Požiūrio atspindys ir formavimas. Retrieved from $\mathrm{http}: / / w w w . c i v i t a s .1 t / f i l e s /$ Emigracija_pranesimai.pdf

Migration Integration Policy Index. (2014). Country report: Lithuania. Turku, Finland: Author.

Morkevicius, V., \& Norkus, Z. (2017). Towards rediscovery of social class after the post-communist transition: A comparative neo-Weberian analysis of Baltic States. Filosofija, Sociologija, 28(2), $128-138$

Niebuhr, A. (2010). Migration and innovation: Does cultural diversity matter for regional R\&D activity? Papers in Regional Science, 89, 563-585.

Prytula, Y., \& Pohorila, N. (2012). Socio-economic determinants of international migration. Journal of Identity \& Migration Studies, 6(1), 3-26.

Psacharopoulos, G., \& Woodhall, M. (1997). Education for development: An analysis of investment choices. New York, NY: Oxford University Press. 
Stankuniene, V. (1996). Mobility of scientists in Lithuania: Internal and external brain drain. Vilnius, Lithuania: LFSI.

Statistics Lithuania. (2011). Lithuanian 2011 population census in brief. Vilnius, Lithuania: author.

Statistics Lithuania. (2012). Lithuanian 2011 Population Census in Brief/ 2011 m. gyventojų surašymo rezultatai. Vilnius, Lithuania: author.

Statistics Lithuania. (2014). Database of indicators. Retrieved from https://bit.ly/21G54Oy

Statistics Lithuania. (2018). Lietuvos gyventoju tarptautine migracija. Vilnius, Lithuania: Author.

Stuen, E., Mobarak, A., \& Maskus, K. E. (2010). Skilled immigration and innovation: Evidence from enrollment fluctuations in U.S. doctoral programs. Cambridge, MA: National Bureau of Economic Research.

Taljūnaite, M. (2005). Pilietybe ir socialine Europos integracija. Vilnius, Lithuania: Mykolo Romerio universitetas.

Taljūnaite, M., Gumbreviciute, D., \& Labanauskas, L. (2009). Tyrèjų mobilumas ir jo socialiniai aspektai. Retrieved from http://www.smm.lt/smt/eksp_stud/index.htm

Taljunaite, M., \& Sviklas, K. (2018). Vidurinè klasé Lietuvoje. Vilnius, Lithuania: Lietuvos socialinių tyrimų centras.

Williams, A. M. (2007). Listen to me, learn with me: International migration and knowledge transfer. British Journal of Industrial Relations, 45, 361-382.

Wolburg, M. (2001). On brain drain, brain gain and brain exchange within Europe. Hamburg Institute of International Economics, Hamburg, Germany: Baden-Baden.

Žibas, K. (2015a). Immigration policies in Lithuania: Institutional and legislative developments. Problemy Polityki Społecznej, 31(4), 59-79.

Žibas, K. (2015b). Migration policies: Lithuania (2015). The Population Europe Resource Finder and Archive. Berlin, Germany: Max Plank Institute for.

Zygmantas, J. (2011). Adult newcomers' difficulties in learning Lithuanian: An ethnographic case study (Doctoral dissertation, Vilnius University, Vilnius, Lithuania). 